\title{
プログラム実行パスに基づいた投機スレッド 分割*
}

\author{
大津 金光 ${ }^{\dagger} \cdot$ 小川 大仁 $^{\dagger} \cdot$ 横田 隆史 ${ }^{\dagger} \cdot$ 馬場 敬信 $^{\dagger}$

\begin{abstract}
Program Execution Path-Based Speculative Thread Partitioning*
\end{abstract}

Kanemitsu Ootsu $^{\dagger}$, Hirohito OGawA ${ }^{\dagger}$, Takashi YokотA ${ }^{\dagger}$ and Takanobu BabA ${ }^{\dagger}$

\begin{abstract}
Nowadays, multi-core processor, a multi processor system on a single chip, is widely available, and the processing capacity of computer system is highly extended. However, parallelization of computer program at the thread level, namely multithreading, is required in order to shorten the execution time of (in other words, to speed up) the single program by sufficiently utilizing the power of the multi-core processor.

In this paper, we propose a method of thread partitioning that partitions a single program code into parallel threads. The method intends for programs which is hardly sped up by conventional multithreading techniques, and the method is based on a speculative thread execution model. In the method, a program code is partitioned into threads based on the frequencies of the program execution path (the execution sequence of the program basic blocks). Partitioning of program code along the most frequently executed path and no data dependencies between partitioned threads allow each thread to execute in parallel and the program can be sped up.

For the purpose of clarifing the performance achieved by our proposed method, the method is applied to the practical program code, that is difficult to speedup by utilizing the parallelism at loop level, and the cycle-level processor simulation is performed.
\end{abstract}

\section{1.はじめに}

現在 ,一つのチップ上に複数のプロセッサコアを搭載 したマルチコアプロセッサが広く普及しており，コン ピュータの潜在的な処理性能は飛躍的に向上した．しか し，光の性能を十二分に活用して単一プログラムの実行 時間を短縮するためには，プログラムコードのスレッド レベルでの並列化 (以降 , マルチスレッド化) を行うこと が必要である．しかしながら，プログラムコードのマル チスレッド化処理は一般的には簡単な作業ではなく，こ れを人手により行うためには専門的な知識や経験ととも に多大なる時間を必要とする。

そこで, 従来よりプログラムコードの自動的なマルチ スレッド化処理を行うための研究が行われてきた .とく に，科学技術計算プログラムのような特定の数式に基づ

* 原稿受付 2008 年 7 月 2 日

†宇都宮大学大学院工学研究科 Graduate School of Engineering, Utsunomiya University; 7-1-2, Yoto, Utsunomiya-city, Tochigi 321-8585, JAPAN

Key Words: speculative thread, thread pipelining model, thread partitioning, program execution path.
いた計算処理をひたすら繰り返しながら解くという構造 を持つプログラムでは, プログラムの実行時間の中での ループ処理が占める割合が極めて大きいことから，マル チスレッド化処理の対象としてループ構造に着目する研 究が古くより行われてきた $[1]$. 兴の成果は現在の商用自 動マルチスレッド化コンパイラに取り込まれ，実用に供 されている $[2,3]$.

しかしながら , プログラムにはマルチスレッド化によ り高速化されるループ以外にも逐次処理部分が存在する ため, アムダールの法則により仮にループ処理部分が無 限大に高速化できたとしても，プログラム全体としての 高速化は制限される . 光こで, プログラム中の非ループ 処理部分の高速化が重要となる .

非ループ処理部分に着目したマルチスレッド化による 高速化の研究として, 国内では早稲田大学のマルチグレ イン並列化処理の研究が有名である [4] . マルチグレイン 並列化では , プログラムコード中のサブルーチン , ルー プ, 基本ブロック間での粗粒度並列性を階層的に利用す ることでプログラムの高速化を図る .プログラムをタス クへと静的に分割を行い，光れらのタスク間で最適なス 
ケジューリングを行うことで高速化を達成する .

このマルチグレイン並列化処理により一定のプログラ ムの高速化が達成できるが，プログラムの実行時間は光 の中で最も時間を要する処理部分 (クリティカルパス)よ り短くすることはできない . プログラムの高速化をさら に推し進めるためには，実質的なクリティカルパスを短 縮する方策を採用する必要がある，乥こで本論文では， 投機的マルチスレッド実行モデルを採用することでプロ グラムのクリティカルパス短縮を図る .

投機的マルチスレッド実行モデルとは, 単一プログラ ムを複数のスレッドに分割して並列処理するマルチス レッド実行モデルの一つである . スレッド間での時間的 先行関係 (以降，単に先行関係とよゔ) に関わらず，将 来実行される可能性が高いスレッドや，実行に必要な值 データを高い確度で推定可能なスレッドを前倒しで(投 機的に) 実行することで, プログラムコードの実質的な クリティカルパスを短くして高速化を達成する．

投機的マルチスレッド実行を行うプロセッサの研究は これまで樣々に行われてきた $[5-8]$ が，弚の中でわれわ れは, Tsai らの superthreaded アーキテクチャと光の 投機的スレッド実行モデルであるスレッドパイプライニ ングモデル $[8]$ が , 現在のマルチコアプロセッサアーキ テクチャをべースとして比較的実現が容易であると考え た．乥こで本研究ではこのモデルを前提とする．

投機的マルチスレッド実行によりプログラムの高速化 を達成するためには, 高速化の対象となるプログラム コードをどのように複数のスレッドに分割するかという 問題とともに，いかに投機的なスレッドの実行を成功さ せるかが問題となる．とくに，命令コードによりスレッ ド起動などの制御を行う superthreaded アーキテクチャ では，スレッド制御にかかるオーバヘッドがハードウェ アにより制御を行う投機的マルチスレッドアーキテク チャ [5-7] よりも大きいため, スレッド分割の仕方や投 機成功率の影響を受けやすいと考えられる．光のため高 い性能を実現するスレッド分割方法が必要である．

一方，実際のプログラムの実行に関して，ごく一部の 限られた本数のパス (基本ブロックの列)が頻繁に実行 され，光れ以外のパスは実行されない場合が多いこと が知られている [9-11] . この性質が成り立つということ は，すなわちスレッド間のすべての依存関係を考慮しな くとも頻繁に実行される少数のパスのみに着目してマ ルチスレッド化処理を行っても，すべての場合を考慮し たマルチスレッド化と同等の性能か実質的には達成でき ることを意味している，乥こでわれわれは，プログラム のこの性質を投機的マルチスレッド実行に活用すること で，投機的なスレッド実行の成功率を高めつつ，プログ ラムのスレッド分割処理を容易にできるのではないかと 考えた。

プログラムの実行パスに着目した研究はこれまで樣々 に行われてきた . まず , プログラムの実行パスを正確に
調べるためのパスプロファイリング手法として EPP [11] や SPP[12] などが開発されており，情報の収集コストの 低減を図りつつも正確なパス情報が得られるようになっ ている . 本研究は, これらのパスプロファイリング手法 により得られる正確な実行パス情報に基づいて，高性能 な投機スレッド分割を行うものである。

また，実行パス情報を活用した最適化手法も盛んに研 究されている . プログラムの性能を高めるためのプログ ラム変形 $[13,14]$ や命令コード移動 $[15,16]$, コード配 置 [17]，実行頻度の高いパスに沿った大域的なコードス ケジューリング $[18,19]$ などに実行パス情報が活用され ているが，これらはいずれも命令レベル並列性を活用し た性能向上という点で共通している.本研究もこれらの 研究と同樣に実行頻度の高いパスに注目するものである が，実行パス情報をスレッドパイプライニングモデルに おける性能向上に活用するものであり，スレッド間での データ依存関係が発生しないように実行頻度の高いパス に沿ってプログラムコードを分割し，投機的なマルチス レッド実行によるスレッドレベル並列性の活用により性 能向上を図るものである .

本論文では, superthreaded アーキテクチャおよびス レッドパイプライニングモデルを前提として , プログラ ム中の実行頻度の高いパスに注目したスレッド分割処理 方法を提案し，実際のプログラムに対して適用したシ ミュレーション評価により，提案手法によって達成され る性能を明らかにする .

本論文の構成は以下の通りである．2 節では本論文が 前提とする投機的マルチスレッド実行モデルについて説 明する．つぎに， 3 節にて高頻度で実行されるプログラ ム中の実行パスを考慮したスレッド分割手法を提案し， 4 節で提案手法により達成される性能について評価を行 う. 5 節で関連研究について述べ, 最後に 6 節にてまと める.

\section{2. マルチスレッド 実行モデル}

\section{1 投機的マルチスレッド実行}

本論文では, プログラムの実行時間におけるクリティ カルパスを実質的に短縮するために投機的なマルチス レッド実行モデルを採用する . 投機的マルチスレッド実 行モデルでは, マルチスレッド化の対象となるプログラ ムコードを複数のスレッドに分割したうえで, 本来は先 行関係に基づいて順番に実行されるべきところを，先に 実行されるスレッドの実行が完了する前に，後に実行さ れるべきスレッドを前倒しで実行することで実質的にク リティカルパスを短縮し，実行性能を高めるものである．

Fig. 1 に逐次実行と投機的マルチスレッド実行の関係 を示す . 図において各ノードはプログラムの基本ブロッ ク，実線矢印は基本ブロック間の先行関係を意味する . ここで, たとえば基本ブロック BB1 は关の最後で条件 分岐を行うため次に BB2 を害行するとは限らないもの 


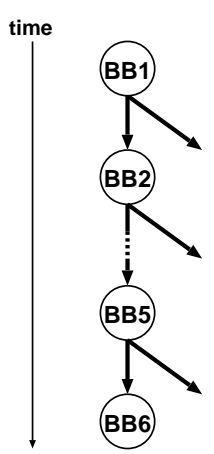

(a) sequential execution

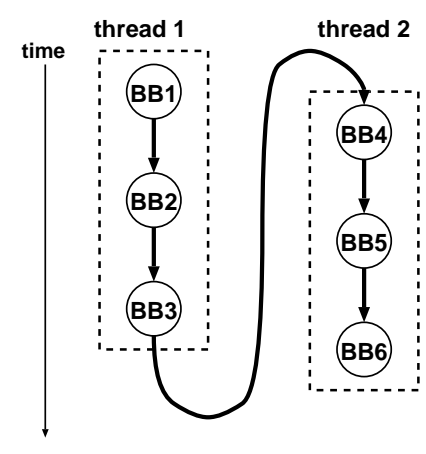

(b) speculative multithread execution
Fig. 1 Sequential execution and speculative multithread execution

とすると，BB2の実行は BB1の実行の完了を待つ必要 がある．关のため，基本ブロック間の先行関係に従い， 本来は図中 (a) に示す通りに基本ブロックを順番に実行 していく必要がある.しかしながら，投機的マルチス レッド実行では，この先行関係に関わらず後続の基本ブ ロックを前倒しで別のスレッドとして並列実行する . 図 中 (b)では BB4 以降を別のスレッドとして BB1〜BB3 の実行が完了する前に実行を開始している．この場合， 先行関係が守られていないので通常の意味では「正しい 実行」ではないが，もし前倒しで実行されたスレッドが， 高確率で実行される，あるいはスレッドの実行に必要な 值データを高い確度で予想可能であり光の予想値を使え ば実行を進めることができるといった場合には , 先行関 係を守らなくても結果的に「正しい実行」が行われる可 能性が高い．もし結果として「正しい実行」が行われれ ば, 前倒しで実行した分だけプログラムのクリティカル パスが短縮され，実行時間が短縮されることになる．

しかし 「正しい実行」になることを期待して前倒しで スレッドを(投機) 実行したとしても，期待通りに「正し い実行」にならない場合 (以降 , この場合を「投機失敗」 とよゔ）もあり，光の場合は投機失敗したスレッドの実 行開始時点の状態に戻してから，先行関係を守った実行 をやり直す必要がある . 投機失敗に伴う状態回復と実行 のやり直しにより実行時間が増えるため，投機的マルチ スレッド実行では投機失敗が起こる確率が性能上重要で あり，投機失敗の確率が低いほど実行性能が高くなる．

投機的マルチスレッド実行では投機失敗に備えて，い つでも状態回復処理と再実行ができるようにしておく必 要がある . 中でも状態回復処理は純粋にオーバヘッドと なるため，この処理にかかるコストを最小限に抑える必 要がある .この状態回復処理をソフトウェアのみにより 実現する場合，光の処理に伴う時間的オーバヘッドが大 きくなり, 性能を落とす要因となるため, プロセッサシ ステム内に投機的なスレッド実行を支援するためのハー ドウェア機構が備わっている方が性能上有利である .

これを背景として，従来より投機的マルチスレッド実
行を行うプロセッサの研究は樣々に行われてきた [5-7].

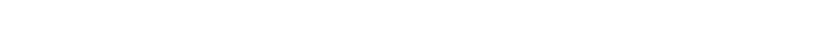
サをべースとした実現が比較的容易であると考えられる Tsai らの superthreaded アーキテクチャ[8]に注目した . 本アーキテクチャでは , 投機実行中のスレッドのメモリ への書き込みデータを, 投機状態が解消される(つまり 実行が確定する) までの期間，一時的保存するための専 用ハードウェアバッファを備える . 投機失敗時には , こ のバッファの内容を破棄することでスレッドの状態回復 処理を高速に行う.

本論文ではスレッド実行モデルとして，この superthreaded アーキテクチャの実行モデルであるスレッ ドパイプライニングモデル $[8]$ を採用する . 次の節にて 本モデルを説明する .

\section{2 superthreaded アーキテクチャ}

Fig. 2 に superthreaded アーキテクチャ [8] を示す . 本 アーキテクチャでは, 従来型の汎用プロセッサコア(図 中 Exeuction UnitおよびLoad/Store Unit) を中心 とした複数のスレッドユニットを同一ダイ上に並べ , L1 命令およびデータキャッシュを各スレッドユニットで共 有する . スレッド間での制御やデータ通信のための通信 ユニット (図中 Comm.Unit) を持ち, 弚れらの間はリン グネットワークで接続されている . スレッド間で依存す るメモリアクセスの監視と投機状態のメモリデータを保 持するためのメモリバッファ(図中Memory Buffer)と， メモリバッファ中の投機的なストアデータをデータキャッ シュを介してメモリに書き戻すライトバックユニット (図 中Write-Back Unit) を備えている.

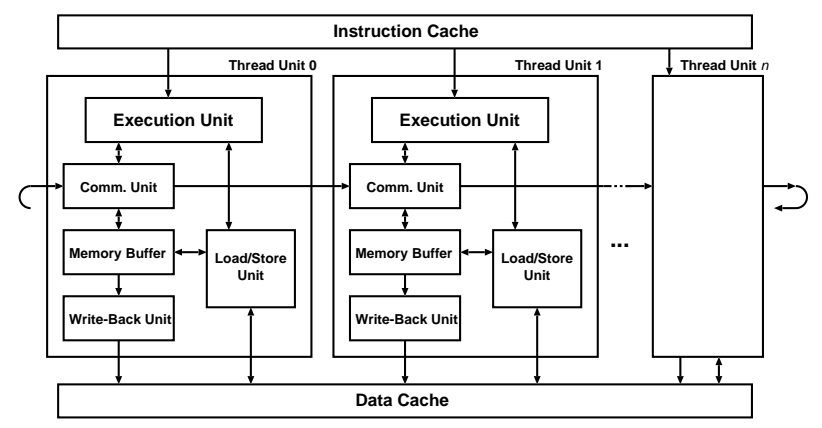

Fig. 2 The superthreaded architecture

\section{3 スレッドパイプライニングモデル}

Fig. 3 にスレッドパイプライニングモデルにおける並列 実行の樣子を示す. 本実行モデルではプログラムを制御 フローに沿って分割を行い, 各スレッドの実行開始後に次 のスレッドを起動することでマルチスレッド実行を開始 する . 各スレッドの実行は Continuation, TSAG(Target Store Address Generation), Computation, Write-Back の四つのステージから構成される .

各スレッドは Continuation ステージから実行を開始 する. Continuation ステージでは, 制御フロー上で後続 


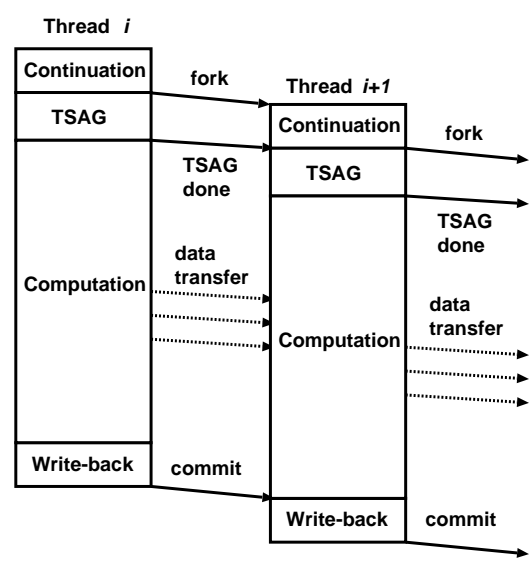

Fig. 3 Thread pipelining model

スレッドの実行を開始するために必要となる変数值の計 算を行い, 次スレッドの起動を行う.

スレッド間にデータの依存関係が存在する場合，ス レッド間で同期をとり計算順序を守る必要がある.この 処理は，スレッド間でのデータ依存を監視する機構を 持った特別なハードウェアメモリバッファ(以降, 単にメ モリバッファとよぶ）を用いることで実現される．この メモリバッファは, 専用の命令により登録される依存変 数のアドレスの監視を行い, 值が先行スレッドによって ストアされるまで後続のスレッドの実行を停止させるこ とで，正しい值の受け渡しを保証する機能を持つ。

TSAG ステージでは, 上記のメモリバッファ監視アド レスの登録を行う . スレッド間でデータ依存となる变数 のアドレスを計算し，メモリバッファに乥のアドレスを 登録する . 先行するスレッドの TSAG ステージが終了す るまで, 各スレッドはこのステージを開始することがで きず，直前のスレッドから TSAG ステージの終了フラグ が送られるまで実行を中断する。

Computation ステージでは, スレッド本来の計算処 理を行う. 光の際に発生するすべてのメモリアクセスは， メモリバッファに対して行われる．スレッド間でデータ 依存となるアドレスとして登録されたアドレスへのロー ドであった場合，先行スレッドによって值がストアされ ているどうか判断する . ストアされていれば, 弚のまま ストアされた值を用いて実行を続ける．しかし，值がス トアされていない場合は, 先行スレッドが值をストアさ れるまで実行を中断し同期を取ることで正しい值を受け 渡す。

Write-Back ステージは, 自スレッドの終了処理を行 い,メモリバッファに格納されている変数の值をメモ リに書き込む．スレッド間の実行順序を守り正しい順 序でメモリへの書き込みを行うために，先行スレッド の Write-Back ステージが終了するまで , 各スレッドは Write-Back ステージを実行することはできない .

以上に述べたスレッドパイプライニングモデルを前提 として，高性能な投機的マルチスレッド実行を実現する
スレッド分割手法を以下に提案する。

\section{3. 実行パスに基づいたスレッド 分割方法}

\section{1 分割の方針}

スレッドパイプライニングモデルでは, 各スレッドが 次のスレッドを明示的に起動することでマルチスレッド 実行を実現する .このモデルにおいてスレッド間の並列 性を最大限に高めるためには, 各スレッドの実行開始直 後のできるだけ早い時期に次のスレッドを起動する必要 がある．弚のためには, 次スレッドの実行開始アドレス を静的に決定できる必要がある．

また，本モデルではスレッド間でのデータ転送が命令 コードにより明示的に制御されるため，スレッド間の データ通信にかかるコストは小さくない，とくに，粒度 の小さいマルチスレッド実行を行う場合には光の影響 か顕著になる．弚のため, マルチスレッド実行によって 性能を最大限に高めるには, スレッド間のデータ依存に よってスレッド間での同期待ちが発生しないようにする 必要がある．弚のためにはスレッド間にデータ依存関係 が発生しないようにマルチスレッド化を行う必要がある．

さらに, スレッドの起動・終了に伴うコストは一般的 に小さくはなく, 1 スレッド当たりの処理サイズが小さ い場合は性能向上が期待できないため, 性能向上のため にはスレッドサイズを大きくする必要がある .

上記三つの要件を考慮に入れたスレッド分割方法とし て , プログラム内の各サブルーチンの開始点と互いに 制御独立 [20]な基本ブロック境界の中からブロック間で データ依存関係が存在せず, 各スレッドのコードサイズ が高速化に必要な閾值以上になるような境界を見つけ出 して乥こをスレッドの分割点とする方法が考えられる． 制御独立な基本ブロック境界を分割点とすることによっ て, 次に実行されるスレッドの実行開始点を静的に一意 に決定できるため, 各スレッドの実行開始後すぐに次の スレッドの実行開始が行える. 基本ブロック間でデータ 依存関係が存在しない分割点を求めることによって, ス レッド間でのデータ通信に伴う同期待ち時間が発生し ないようにできる．また，各スレッドのコードサイズが 一定以上になるような分割点を求めることによって，ス レッド制御に伴うオーバーヘッドによる性能低下要因を なくし，マルチスレッド実行により確実に性能向上を達 成する。

上記のスレッド分割方法によって論理的にはプログラ ムの確実な性能向上が達成できると考えられる．しかし ながら，この方法にはデータ依存関係が基本ブロック間 に存在しないようなブロック境界が見つかるとは限らず， 結果として必ずしもプログラムが複数のスレッドに分割 されるとは限らないという問題点がある. 兴のため, 実 際にこの分割手法を適用できるプログラムか限定される ものと考えられる .

この適用範囲の狭さの問題を解決すべく，われわれは 
プログラムの実行パスに着目した .ここで害行パス (以 降，パスとよぶ）とは，プログラムの基本ブロックの実 行系列である . 実際のプログラムの実行においてはごく 一部の限られたパスが頻繁に実行され，光れ以外のパス は実行されない場合が多いことが知られている [9-11] . 弚のため，実行される可能性のあるすべてのパスに関し てデータ依存関係を考慮しながらスレッド分割を行う必 要はない，光のことから，実行される確率の高いパスに 限定してデータ依存関係を考慮することでスレッド分割 候補となるブロック境界の選択肢か増し，弚の結果とし てプログラムを複数のスレッドに分割できる機会か増や せるとわれわれは考えた .

以下，最も実行頻度の高いパス (以降，最頻度パス) に 沿ったスレッド分割方法について述べる．

\section{2 最頻度パスに沿ったスレッド 分割}

Fig. 4 に最頻度パスに沿ったスレッド分割の樣子を示 す . 図において各ノードは基本ブロックで, 網掛けのも のが最頻度パス上のブロックを示す．

まずは，スレッド分割の対象となる最頻度パスを決定 するために , パスプロファイル [11]などにより分割対象 コード領域でのパスの実行頻度を調べる ${ }^{1}$ (Fig. 4(a)) .

つぎに, 最頻度パスに沿って基本ブロック間にデータ 依存関係があるかどうかを調べる．データ依存関係が 存在しない基本ブロック間を境界としてマクロブロック を形成する .ここで，パス上にループを含む場合は谷の ループを一つのブロックとして扱う (Fig.4(b)) .

最後に , 各スレッドのサイズが一定サイズ以上になる ように，各マクロブロックのサイズを調へ，閾值未満の 命领数のマクロブロックをサイズの小さいものから順に 直前のブロックに統合する (Fig. 4(c)) .ここでの閾値は ターゲットマシンに依存する值であり，マルチスレッド 実行時のスレッド制御コストによる性能低下を上回って 性能向上が可能な最低限のスレッドコード命令数である . 後述の評価環境においては各スレッドが 20 個以上の命 令を含むことができればマルチスレッド実行により性能 向上が可能であるため, 閾值を 20 命令としている.最 終的に得られたマクロブロックを乥れ別のスレッド として並列実行する (Fig. 4(d)) .

Fig. 5 に上記の分割の結果を使ったマルチスレッドの 実行の樣子を示す . 各スレッドは実行開始の初期の段階 で次のスレッドを次々と生成していくことで，マルチス レッド実行状態に入る . 実際に実行されるパスが最頻度 パスを外れた場合は後続のスレッドの実行は正しくない ことになるため，最頻度パスから外れたことが判明した 時点で後続スレッドの実行を破棄して回復処理を行う必 要がある . 回復処理が終了した後は，投機失敗したコー ド部分についてシングルスレッド実行により正しいパス

\footnotetext{
1パスの実行頻度情報を得るために , プログラムを最低 一度は実行する必要がある。
}

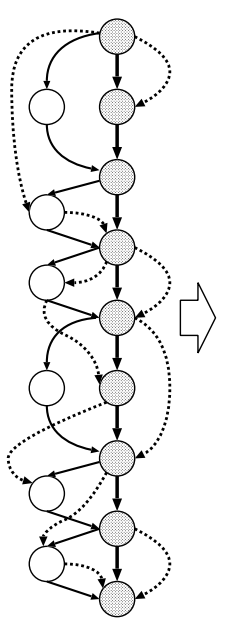

(a) original CFG

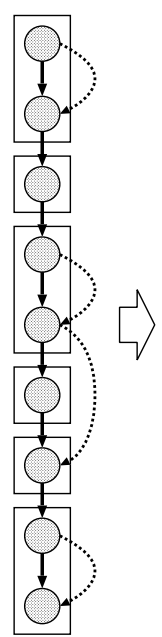

(c) merge block

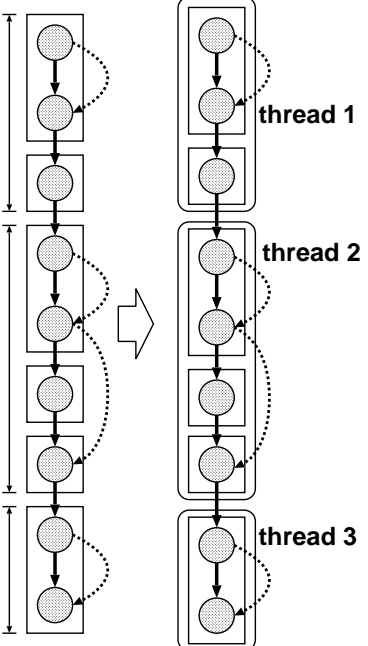

$\longrightarrow$ control flow $\quad$....

Fig. 4 Thread partitioning along the most frequent path

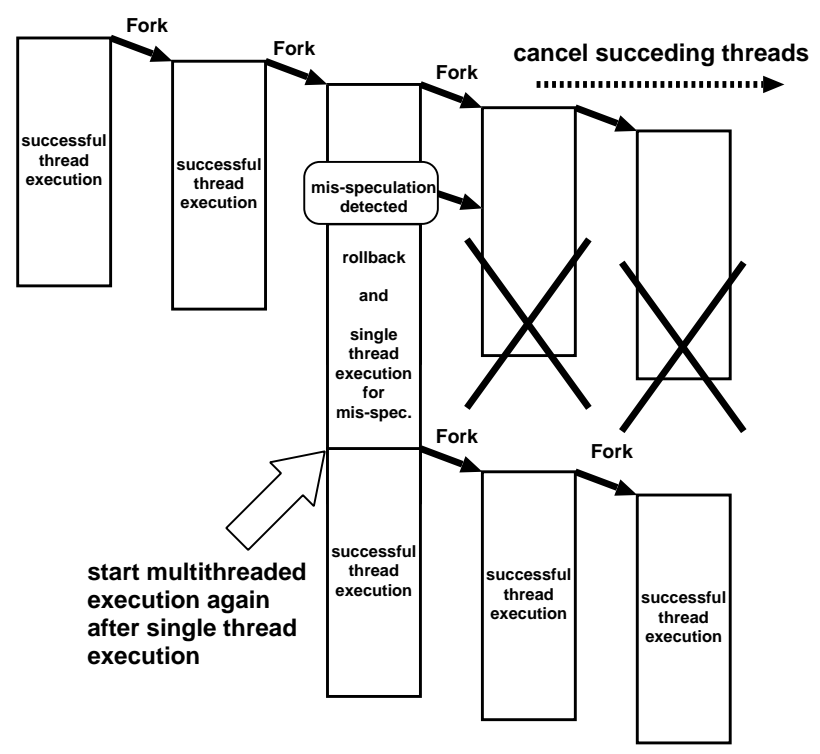

Fig. 5 Multithreaded execution along control flow

を実行し直す，弚の後，マルチスレッド実行を再開する． 最頻度パスに注目したスレッド分割方法には以下の二 つの利点がある .一つは, スレッド分割処理が行いやす くなることであり，もう一つは, 並列実行時の性能低下 の要因となるスレッド間のデータ依存関係を削減できる ことである.

前者について，とくに非数值処理系プログラムにおい ては，不規則な制御構造と複雑なデータ依存関係が多く 存在しがちであり $[21]$, 弚の制御構造とデータ依存関係 を考慮に入れながら最適なスレッド分割ポイントを決定 することは難しい .

しかし，パスの実行頻度情報を用いてスレッド分割処 理の対象を頻度の高いパスに限定することで, スレッド 分割処理を大幅に単純化できる. 
また，後者について，スレッド分割の対象を最頻度パ スに限定することで，最頻度パスが実行される限りにお いて不要なスレッド間のデータ依存関係を考慮する必要 がなくなる．さらに，スレッド間依存変数によってはパ スを限定することで静的に值が決定可能になる場合もあ り，これを用いての定数伝播など最適化の機会が増加す る可能性がある.

しかし一方で, 以下の二つの欠点も持つ .一つは , パ スの実行頻度情報を得るために最低でも一度はプログラ ムを実行する必要があることである．もう一つは, 最頻 度パスから実行が外れた場合の性能低下の問題である。

前者について, 本スレッド分割処理は実行頻度の高い パスを分割の基準として扱うため, 分割対象コードにお けるパスの実行頻度情報が必要であり，产の情報を取得 するためにパスプロファイルを行うなどプログラムを一 度実行する必要がある．この問題については，もしパ スプロファイル情報に基づいてスレッド分割された対象 コードが何度も繰り返し実行されることになれば，実際 上は相殺されると考えられる.ただし , プログラムの入 カデータセット等によって最頻度パスか変わることがあ りえるため, 最頻度パスの決定に際しては慎重に行う 必要があるが，この問題の根本的な解決には，低オーバ ヘッドなパスプロファイル手法 $[11,12]$ 等を活用した動 的なコード生成・切替え手法を導入する必要があると考 えられる.この最頻度パスの変更問題への対応について は, 今後の検討課題である .

また，後者について，実行が最頻度パスから外れた場 合 , パスから外れた地点以降のスレッド実行は不正な実 行であるため実行を破棄し，不正な実行を行う直前の状 態まで回復処理を行う必要がある.さらに, 回復処理の 後，あらためて正しい実行をやり直すため，回復処理と 再実行にかかるコストにより性能が低下する可能性が ある。

最頻度パスの実行確率が高い場合は, 実行のやり直し が起きる確率は低くなるため，性能が低下する可能性は 小さいと考えられる．一方，最頻度パスの実行確率が低 い場合は，実行のやり直しが起きる確率は高くなり，性 能が低下すると考えられる．最頻度パスの実行確率が 低い場合への対応としては, 最頻度パスに隣接する基本 ブロックの中からスレッド間に新たなデータ依存関係を 生じないものに限定して, スレッドコードに含めていく ことで，投機失敗の機会を減らすという方法が考えられ る. Fig. 6 に炎の例を示す.最頻度パスに沿って二つの スレッド $i$ と $i+1$ があるものとする . この図において , もし基本ブロック 3 が実行された場合は最頻度パスから はずれることになるため, スレッド $i+1$ の実行は破棄さ れる.このとき，もし基本ブロック 3 がスレッド $i+1$ と の間にデータ依存関係を持たなければ，基本ブロック 3 をスレッド $i$ に含めることでスレッド $i+1$ の実行は破棄 する必要がなくなる .このような処理を施すことによっ

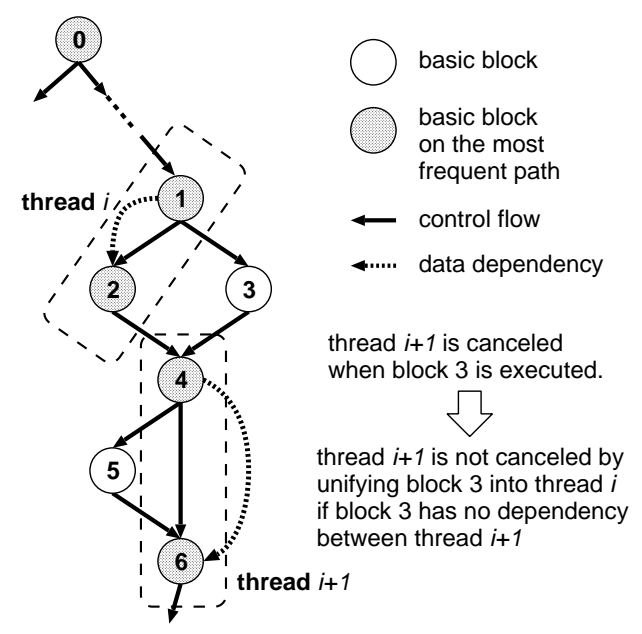

Fig. 6 Reduction of miss-speculation

て，投機失敗の機会を減らすことができると考えられる． ただし，実行パスに関する先行研究により，ごく一部 の限られた本数のパスが実行時間の大部分を占めるこ とが示されており [9-11], また，実行頻度の高いパスに 沿った大域的なコードスケジューリング $[18,19]$ をはじ めとする各種最適化処理の研究事例が光の効果を発揮し ていることから, 実際上は, 最頻度パスの実行確率は高 い場合が多いと予想される. 光のため, パス統合が必要 となる場合はある程度限られると考えられる．

\section{4. 本分割手法による性能}

最頻度パスに基づいたスレッド分割手法によりどの程 度の性能が達成可能であるかを，(1) 最頻度パスの実行 確率の性能への影響，(2) 負荷バランスの性能への影響， の観点から評価する .

性能評価の対象として，SPEC CINT2000[22] の中か らループ並列性の低いプログラムコードを使用する . ス レッド分割対象となるコードに対して, 前節で述べたス レッド分割処理を手動により適用する。性能評価は，プ ロセッサコア内部の命令パイプラインやキャッシュメモ リの挙動を正確に模擬できるスレッドパイプライニング モデルシミュレータである $S I M C A[23]$ を用いて行う.乥 のため，現実に近い性能評価を行うことができる.シン グルスレッド実行した場合のサイクル数とマルチスレッ ド実行した場合のサイクル数を計測し, 弚れらの比を取 ることで性能向上率を算出することにより達成可能な性 能を明らかにする .

\section{1 評価方法}

本評価ではコンパイラの最適化処理の影響を極力受 けない形での性能比較を行うために，機械語レベルで のスレッド分割を行って評価を行う.評価対象プログラ ムのソースコードをSIMCA 用 $g c c$ クロスコンパイラ (version 2.7.2.3ベース)でコンパイルして実行可能バイ ナリコードを生成する、最適化オプションとして - O3(最 高レベルの最適化)を使用し, コンパイラによって十分 
に最適化を行う.生成されたバイナリコードに対して 3 節で述べた実行頻度の高いパスに注目したスレッド分割 を適用し，マルチスレッド化コードを生成する．変換対 象コードの開始から終了までの実行サイクル数を，シン

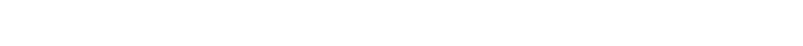
いて計測し，両者の比を求めることで速度向上率を算出 する .

SPEC CINT2000 ベンチマークでは実行時間の長い 順に ref, train, testの 3 種類の入力データセットが用意 されているが，本評価では評価に多大な時間を要する プロセッサシミュレーションを行う都合上，現実的なシ ミュレーション時間内で評価データを取得するために， 入カデータセットとして train および testの 2 種類の データセットを用いる.シミュレーションパラメータを Table 1 に示す .これらはすべて SIMCA の標準的な設 定值である

Table 1 Simulation parameters

\begin{tabular}{|c|c|}
\hline thread unit & $\begin{array}{c}\text { 4-way superscalar } \\
\text { out-of-order execution } \\
5 \text { stage pipeline }\end{array}$ \\
\hline L1 cache (I) & $\begin{array}{c}\text { direct-map } \\
16 \mathrm{~KB} \text { (line size } 32 \mathrm{~B}) \\
\text { access latency } 1 \text { cycle }\end{array}$ \\
\hline L1 cache (D) & $\begin{array}{c}4 \text {-way set-associative } \\
16 \mathrm{~KB} \text { (line size } 32 \mathrm{~B}) \\
\text { access latency } 1 \text { cycle }\end{array}$ \\
\hline L2 cache (I+D) & $\begin{array}{c}4 \text {-way set-associative } \\
256 \mathrm{~KB} \text { (line size } 64 \mathrm{~B}) \\
\text { access latency } 6 \text { cycles }\end{array}$ \\
\hline main memory & $\begin{array}{c}8 \text { bytes/cycle } \\
\text { access latency } 18 \\
\text { cycles }\end{array}$ \\
\hline inter-thread communication & $\begin{array}{c}16 \text { bytes } / \text { cycle } \\
\text { access latency } 1 \text { cycle }\end{array}$ \\
\hline memoy buffer & $\begin{array}{c}512 \text { bytes } \\
\text { access latency } 1 \text { cycle }\end{array}$ \\
\hline
\end{tabular}

\section{2 評価結果}

Table 2 はSPEC CINT2000の 175.vprの関数 init_chan を対象として本論文で提案のスレッド分割手法を適用し た場合と，ループのイテレーション単位でスレッド分割 した場合での性能比較を示したものである . 本対象コー ドをループのイテレーション単位でスレッド分割して 4 スレッドで並列実行した場合に，最大で 1.76 倍に性能向 上することを確認している(表中 loop-baseの欄) . 理想 的には , 4 スレッドの並列実行により最高 4 倍の性能が 達成できることから考えると，わずかな性能向上となっ ている。

このようなループの並列実行では性能が上がりにく いコードに対して本提案手法を適用したスレッド分割結 果をFig. 7 に示す . 図において各ノードは基本ブロック，
Table 2 Speedup ratios of init_chan (175.vpr)

\begin{tabular}{|c|r|r|}
\hline data set & path-base & loop-base \\
\hline test & 1.87 & 1.42 \\
train & 1.90 & 1.76 \\
\hline
\end{tabular}

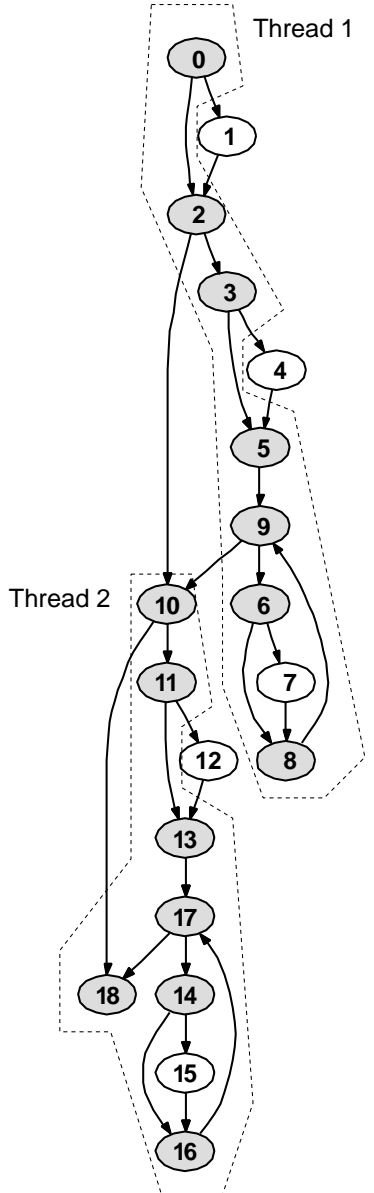

Fig. 7 Thread partitioning result of init_chan (175.vpr)

矢印はブロック間の遷移先, グレイのノードは最も頻度 の高いパス上の基本ブロックを示している .この関数に おいて test, trainの両データセットともにこのパスが $100 \%$ 実行される.結果として図に示すように,対象コー ドが二つのスレッドに分割された .

この二つのスレッドによるマルチスレッド実行により 最大 1.90 倍の速度向上が達成できることを確認でき，本 提案手法によりループ並列度の低いコードに対して高速 化を達成できた .

本提案手法は最頻度パス実行確率によって実行性能 が影響を受ける．前述の 175.vpr init_chanでは最頻度 パスの実行確率が $100 \%$ であるため，実行パスが最頻度 パスから外れる場合の性能低下が発生しない，最頻度 パスから実行が外れる可能性のある場合の適用例とし て, 300.twolfの関数 strtolでの速度向上率を Table 3 に 示す.このコードもループ並列度が低いコードであり， test , train のいずれの場合もループ並列を活用したマ ルチスレッド実行 (4 スレッド実行)の性能はシングルス 
Table 3 Speedup ratios of strtol (300.twolf)

\begin{tabular}{|c|r|r|}
\hline data set & path-base & loop-base \\
\hline test & 1.16 & 0.71 \\
train & 1.07 & 0.69 \\
\hline
\end{tabular}

Table 4 Speedup ratios of hbCreateDecodeTables (256.bzip2)

\begin{tabular}{|c|r|r|}
\hline data set & path-base & loop-base \\
\hline test & 1.08 & 0.99 \\
train & 1.00 & 0.99 \\
\hline
\end{tabular}

Table 5 Ratios of thread load balance

\begin{tabular}{|c|r|r|}
\hline data set & 175.vpr & 256.bzip2 \\
\hline test & 0.96 & 0.28 \\
train & 0.97 & 0.23 \\
\hline
\end{tabular}

レッド害行よりも低下するが, 本提案手法の適用により 高速化が可能である .

このコードにおいて, 最頻度パスの実行確率は testの 場合で $72.1 \%$, train の場合で $57.5 \%$ である.最頻度パ スの実行確率が高いほど，実行のやり直しに伴う性能 低下の機会が減るため実行性能が高くなる . Table 3 で の本提案手法による速度向上率を見ると，testの場合で 1.16 倍, trainの場合で 1.07 倍という結果になっており， 最頻度パスの実行確率が高いほど性能が高くなっている． このことから最頻度パスを正確に見つけ出す必要がある ことがわかる .

本提案手法では最頻度パスの実行確率が高いほど高 性能が達成されるが，光のほかに分割後の各スレッド 間の負荷バランスも性能に大きく影響する. Table 4 は 256.bzip2の関数 hbCreateDecodeTablesでの速度向上率 を示す .このコードはinit_chanの場合と同樣に最頻度パ スの実行確率が $100 \%$ である.いずれのコードも分割の 結果，二つのスレッドでのマルチスレッド実行が行われ る. Table 2 と Table 4 光れ光れにおいて本提案手法によ る速度向上率を比較すると, Table 4 の方の性能が低い． これはスレッド間での負荷バランスの違いによる結果で ある. Table 5 は init_chan と hbCreateDecodeTablesに おけるスレッドの負荷バランス率を示したものである．

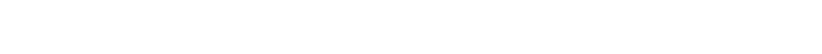
行サイクル数の小さい方を大きい方で割ったものである .

表より, 速度向上率の高いinit_chanのバランス率が 1 に近く，二つのスレッド間でのバランスが取れている 一方で, 速度向上率の低い hbCreateDecodeTables のバ ランス率が小さくなっており, 二つのスレッド間でのバ ランスが取れていないことがわかる.このことから，ス レッド間での負荷バランスが取れていることが高速化の ためには必要であることがわかる .

ここまで, ループに基づいたスレッド分割と本提案手 法の性能比較を行い, 性能が向上することを示した . こ
の性能は 3.1 節の序盤で述べた制御独立な基本ブロック 境界で分割する手法によっても，もしスレッド分割がで きれば同樣に高速化を達成できるものと推測されるが， 制御独立なブロック境界での分割ではスレッド間のデー 久依存関係により，乥も光もスレッド分割ができないと いう問題があった . 本提案手法はこの問題の解決のため に最頻度パスに限定したスレッド分割を行うものである． 乥こで, 最頻度パスに限定することで, スレッド分割の 機会が増えることについて述べる。

Fig. 8 は 300.twolfの関数 accepttの制御フローグラフ である.図において, 関数の開始点と互いに制御独立な 基本ブロックは関数の終端であるブロック 8 のみであり， ブロック 8 は関数の終了コードであるためコードサイズ が小さい，弚のため，この関数においては制御独立なブ ロックでのスレッド分割はできない ,一方, 図中のグレ イのノードで表している最頻度パスに基づいてスレッド 分割を行うと，三つのスレッドへの分割が可能である. すなわち, この関数は制御独立なブロックではマルチス

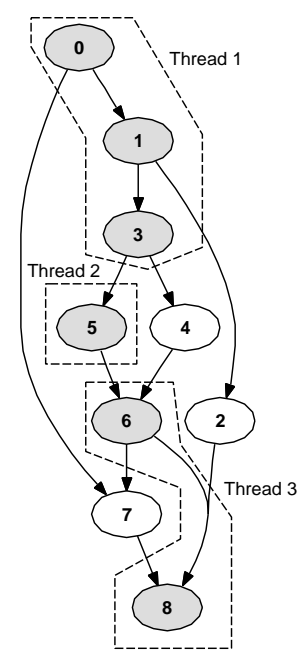

Fig. 8 Control flow of acceptt (300.twolf)

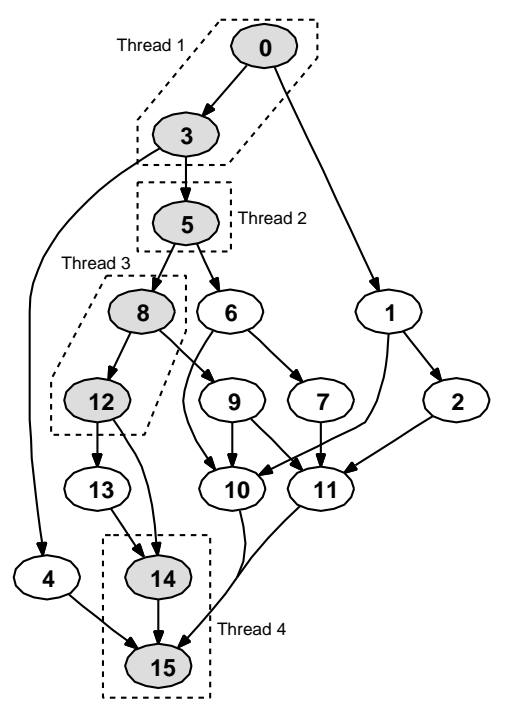

Fig. 9 Control flow of pow_P (175.vpr) 
レッド化できないのに対し，パスベースの分割ではマル チスレッド化ができるということである .

Fig. 9 は 175.vpr の関数 pow_Pの制御フローグラフ である.この場合も同樣に，関数の開始点と互いに制御 独立な基本ブロックは関数の終端のブロックのみであり， 制御独立なブロックでのスレッド分割はできない，一方， この関数に対してパスベースの分割を行うと，四つのス レッドへの分割が可能である .

このように，制御独立なブロックでの分割ではマルチ スレッド化ができないコードに対して，本提案手法を適 用することでマルチスレッド化が可能である

以上の評価結果より，本論文で提案のスレッド分割手 法で , ループ並列度の低いコードを対象として最も実行 頻度の高いパスに沿ったスレッド分割により高速化が達 成可能であることが示された .さらに, 関数の入口と互 いに制御独立な基本ブロックでの分割ではマルチスレッ ド化ができないコードに対して本手法を適用することで， マルチスレッド化が可能となることも示された．また， 本手法により高速化を達成するためには，最頻度パスを 正確に見つけ出す必要があること，またスレッド間での 負荷バランスが取れるようにスレッド分割を行う必要が あることが明らかとなった 。

\section{5. 関連研究}

マルチスレッド実行においてスレッド分割は最も重要 な処理であり，この処理の結果により性能が大きく変換 するため，高性能なスレッド分割に向けた研究が従来よ り行われている.

本研究で害行モデルとして採用しているスレッドパイ プライニングモデル $[8]$ を考案した Tsai らは , 彼らの実 行モデルのためのスレッドコード生成手法についても提 案を行っている．しかし，Tsai らはループを対象とした マルチスレッド化のみを考えており，非ループ部分のマ ルチスレッド化については何も検討していない . われわ れはスレッドパイプライニングモデルの有用性に着目し， プログラム中のループ以外の部分も高速化することでプ ログラムの実行性能を従来以上に高めることを目的とし てパスに沿ったスレッド分割方法を開発した 。

Vijaykumar らは投機的マルチスレッド実行モデルの 一つである Multiscalar 実行モデル [5]を前提として，経 験的方法によるスレッド分割手法を提案した $[24]$. 彼ら の手法において，スレッド制御コストの性能に与える影 響を小さくするためにスレッドサイズが一定命令数以上 になるようにスレッド分割を行う点は, われわれの研究 と同じである．しかし，前提とするスレッド実行モデル の違いによる相違が存在する . 彼らの手法ではすべて のパスの実行の可能性を対等に扱っており，次にどのス レッドが実行されるかについては Multiscalar のハード ウェアにより予測されることを前提としている．この予 測ハードウェアは一定数の遷移先までしか情報を保持で
きないため，投機成功率を高めるためには各スレッドの 遷移先 (つまり各スレッドに含まれる条件分岐の数) を 一定数以下に抑える必要がある .この制約によりスレッ ドサイズを大きくできないという問題が起こる．また， このことからスレッドの分割地点の自由度についても大 きく制限されるため, スレッド間データ依存のない形で のスレッド分割の実現も困難となる . われわれの手法で は後続スレッド候補が一定数以内になるようにする必要 はなく，したがってスレッドサイズについての制約もな い.また，スレッド分割の自由度も高いため，スレッド 間データ依存のない形でのスレッド分割の実現が容易で ある

実行頻度の高い実行パスに沿ってスレッド分割を行う 処理はハードウェアによっても行うことができる．兴の 事例として，トレースプロセッサ [7] が挙げられる . ト レースプロセッサでは特殊な命令キャッシュに格納され ているホットトレース (本論文におけるパスに相当する) の中から次に実行される可能性の高いトレースを予測し ながら，各トレースを投機的に並列実行することで高速 化を達成する．ハードウェアによりスレッド分割を行っ ているため，実行頻度の高いトレースを早急に見つけ出 して投機的に並列実行できるという利点を持つが，ハー ドウェアの現実的制約により，原理上はプログラムコー ドの解析能力を高くすることができないため，必ずしも 高性能なスレッド分割が実現されるわけではない .

本論文ではソフトウェアによりスレッド分割処理を行 うため, プログラムコードの解析能力がハードウェアに よる処理とは比較にならないほど高く, 最適なスレッド 分割を実現できる可能性が大きい .

\section{6. おわりに}

本論文では, 従来のマルチスレッド化では高速化が難 しいプログラムコードを対象として，投機的なスレッド 実行モデルであるスレッドパイプライニングモデルを前 提に, プログラム中の実行頻度の高いパスに注目したス レッド分割方法について述べた . 本手法では, 最も頻繁 に実行される実行パスに沿ってスレッド分割を行うこと で，スレッド分割処理を大幅に単純化するとともに，性 能低下の要因となるスレッド間のデータ依存関係を削減 することができるものである .

また , SPEC CINT2000 のプログラムの中からルー プ並列性が低いプログラムコードに対して提案手法を適 用し，シミュレーションにより実行性能の評価を行った。 产の結果，ループ並列性の低いプログラムコードに対し て，スレッド間でのデータ依存を発生させることなくス レッド分割され，本手法の適用により速度向上を達成す ることを確認した . また , 高速化を最大限にするために は，最頻度パスを正確に見つけ出すことと，スレッド間 の負荷バランスを取ることが必要であることがわかった . 本論文における今後の課題としては，本手法に基づい 
た自動マルチスレッド化処理システムの開発が挙げられ る . 本論文での評価では手動によりスレッド分割および スレッドコード生成を行ったため, 評価対象としたプロ グラムコードのサイズに関して制約を受けていた .評価 結果においてスレッド分割数が少ないのはこのためであ るが , これは自動化システムの開発により解決できるも のと考えられる.今後, 自動化システムを開発し，変換 対象コードのサイズおよび分割スレッド数の拡大を図る ことで，本手法の有効性を確実なものとすることを目 指す．

\section{謝辞}

本研究は, 一部日本学術振興会科学研究費補助金 (基 盤研究 (B)18300014，同 (C)19500037)，および宇都宮 大学重点推進研究の援助による.

\section{参考文献}

[1] D. F. Bacon, S. L. Graham and O. J. Sharp: Compiler transformations for high-performance computing; ACM Computing Surveys, Vol. 26, No. 4, pp. 345-420 (1994)

[2] X. Tian, E. Su, D. Kreitzer, H. Saito, R. Krishnaiyer, A. Kanhere, J. Ng, C.-C. Lim and S. Ghosh: Inside the intel 10.1 compilers: New threadizer and new vectorizer for intel core 2 processors; Intel Technology Journal, Vol. 11, No. 4, pp. 263-274 (2007)

[3] IBM: Overview of the IBM XL C/C++ and XL Fortran compiler family (2007)

[4] 岡本, 合田, 宮沢, 本多, 笠原: OSCAR マルチグレイン コンパイラにおける階層型マクロデータフロー処理手 法; 情報処理学会論文誌, Vol. 35, No. 4, pp. 513-521 (1994)

[5] G. S. Sohi, S. E. Breach and T. N. Vijaykumar: Multiscalar processors; Proc. of 22nd Annual International Symposium on Computer Architecture (ISCA), pp. 414-425 (1995)

[6] P. Marcuello and A. González: Clustered speculative multithreaded processors; Proc. of 13th International Conference on Supercomputing, pp. 365-372 (1999)

[7] E. Rotenberg, Q. Jacobson, Y. Sazeides and J. E. Smith: Trace processors; Proc. of the 30th Annual International Symposium on Microarchitecture, pp. 138-148 (1997)

[8] J.-Y. Tsai, J. Huang, C. Amlo, D. J. Lilja and P.C. Yew: The superthreaded processor architecture; IEEE Transactions on Computers, Special Issue on Multithreaded Architectures, Vol. 48, No. 9 (1999)

[9] E. Duesterwald and V. Bala: Software profiling for hot path prediction: Less is more; Architectural Support for Programming Languages and Operating Systems (ASPLOS IX), pp. 202-211 (2000)

[10] T. Ball and J. R. Larus: Programs follows paths; Technical report, Microsoft Technical Report MSR-
TR-99-01 (1999)

[11] T. Ball and J. R. Larus: Efficient path profiling; Proc. of Annual International Symposium on Microarchitecture, pp. 46-57 (1996)

[12] 安江, 菅沼, 小松, 中谷: 動的コンパイラにおける実 行時経路情報の構造的収集手法の提案; Transaction of Information Processing Society of Japan, Vol. 44, pp. 24-35 (2003)

[13] G. Ammons and J. R. Larus: Improving data-flow analysis with path profiles; Proc. of ACM SIGPLAN 1998 Conference on Programming Language Design and Implementation, pp. 72-84 (1998)

[14] R. Gupta and M. L. Soffa: Complete removal of redundant expressions; Proc. of ACM SIGPLAN 1998 Conference on Programming Language Design and Implementation, pp. 1-14 (1998)

[15] R. Gupta, D. A. Berson and J. Z. Fang: Path profile guided partial dead code elimination using prediction; Proc. of International Conference on Parallel Architectures and Compilation Techniques (PACT'97), pp. 102-113 (1997)

[16] R. Gupta, D. A. Berson and J. Z. Fang: Path profile guided partial redundancy elimination using speculation; Proc. of International Conference on Computer Languages (ICCL'98), pp. 230-239 (1998)

[17] K. Pettis and R. C. Hansen: Profile guided code positioning; Conference on Programming Language Design and Implementation (PLDI'90), pp. 16-27 (1990)

[18] C. Young and M. D. Smith: Better global scheduling using path profiles; Proc. of 31st Annual ACM/IEEE International Symposium on Microarchitecture (MICRO-98), pp. 115-123 (1998)

[19] C. Young and M. D. Smith: Static correlated branch prediction; ACM Transactions on Programming Languages and Systems, Vol. 21, No. 5, pp. 1028-1075 (1999)

[20] 中田: コンパイラの構成と最適化, 朝倉出版 (1999)

[21] 小林, 小川, 岩田, 安藤, 島田: 非数值計算応用向けスレッ ド・レベル並列処理マルチプロセッサ・アーキテクチャ sky; 情報処理学会論文誌, Vol. 42, No. 2, pp. 349-366 (2001)

[22] SPEC (Standard Performance Evaluation Corporation); http://www.spec.org/

[23] J. Huang: The SImulator for Multi-threaded Computer Architecture(SIMCA), Release 1.2, (2000); http://www.cs.umn.edu/research/Agassiz/Tools/ SIMCA/

[24] T. N. Vijaykumar and G. S. Sohi: Task selection for a multiscalar processor; Proc. of Annual International Symposium on Microarchitecture, pp. 81-92 (1998) 


\section{著者略歴}

\section{势津架架光 (正会員)}

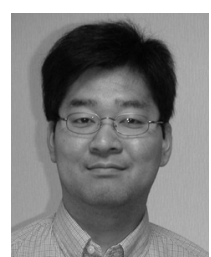

1969 年 10 月 12 日生. 1993 年東京大学 理学部情報科学科卒業, 1995 年東京大学 大学院修士課程修了, 1997 年東京大学大 学院博士課程退学. 同年より宇都宮大学工 学部助手, 2007 年より同助教. 計算機アー キテクチャおよび並列処理の研究に従事 .

博士 (情報理工学) . FPGA/PLD Design Conference 2002 審査委員特別賞, PDCAT'05 Outstanding Paper Award, IASTED PDCS2002, PDCS2008 Best Paper Award 各受 賞 . 情報処理学会会員 .

\section{京乫梁㳕}

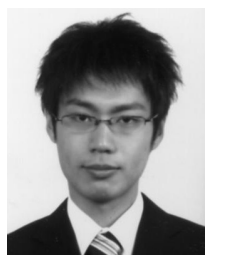

1984 年 8 月 28 日生 . 2007 年宇都宮大 学工学部情報工学科卒業, 2009 年同大学 院工学研究科情報工学専攻修士課程修了. 並列処理向けのプログラムコード生成手法 の研究に従事 .

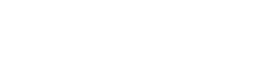

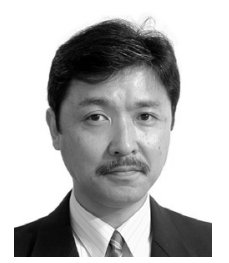

1960 年 10 月 10 日生. 1983 年慶應義塾 大学工学部電気工学科卒業, 1985 年同大学 院電気工学専攻修士課程修了. 同年三菱電 機(株)に入社, 中央研究所, 先端技術総合 研究所, 産業システム研究所に所属, 主席 研究員 .1993 年 12 月から 1997 年 3 月まで 新情報処理開発機構 (RWCP) に出向 . 2001 年 4 月より宇都 宮大学工学部助教授, 2007 年同准教授.計算機アーキテクチャ の研究に従事. 工学博士 . ICCD Outstanding Paper Award (1995) , FPGA/PLD Design Conference 審査委員特別賞 (2002) , PDCAT'05 Outstanding Paper Award (2005) , IASTED PDCS Best Paper Award (2008) 各受賞 . 情報 処理学会, 電子情報通信学会, IEEE 各会員.

\section{䔍場敬 信}

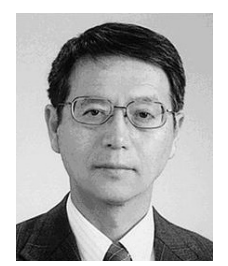

1947 年 11 月 4 日生. 1970 年京都大学 工学部数理工学科卒業, 1975 年同大学院 博士課程単位取得退学。同年より電気通 信大学助手, 講師を経て, 現在宇都宮大学 大学院工学研究科教授. 1982 年より 1 年 間メリーランド大学客員教授. 計算機アー キテクチャ，並列処理などの研究に従事.工学博士 . 1992 年情報処理学会 Best Author 賞, PDCS2002, PDCS2008 Best Paper Award など受賞 . 情報処理学会・電子情報通信 学会各フェロー, IEEE 会員 . 著書に「Microprogrammable Parallel Computer」(MIT Press) , コンピュータアーキテ クチャ (改訂 2 版)」(オーム社) など . 